NBER WORKING PAPER SERIES

\title{
DO ALL NETWORKS FACILITATE INTERNATIONAL COMMERCE? US LAW FIRMS AND THE INTERNATIONAL MARKET FOR CORPORATE CONTROL
}

\author{
Simon J. Evenett \\ Working Paper 9663 \\ http://www.nber.org/papers/w9663 \\ NATIONAL BUREAU OF ECONOMIC RESEARCH \\ 1050 Massachusetts Avenue \\ Cambridge, MA 02138 \\ April 2003
}

I thank participants at the NBER-CEPR-TCER-RIETI conference for their comments and suggestions and am especially grateful to Kyoji Fukao, Jim Harrigan, Takeo Hoshi, Stephen Redding, John Ries, and David Weinstein. Jim Rauch also provided neat comments on a previous version of this paper. My understanding of the determinants and regulation of cross-border mergers and acquisitions has been immeasurably improved by discussions with senior American antitrust practitioners and current and former officials, in particular Bill Kolasky, Bill Kovacic, Jim Rill, Doug Rosenthal, Charles Stark, and Randy Tritell. All remaining errors should of course be attributed to me. The views expressed herein are those of the authors and not necessarily those of the National Bureau of Economic Research.

(C2003 by Simon J. Evenett. All rights reserved. Short sections of text not to exceed two paragraphs, may be quoted without explicit permission provided that full credit including Cnotice, is given to the source. 
Do all networks facilitate international commerce? US law firms and the international market for corporate control

Simon J. Evenett

NBER Working Paper No. 9663

April 2003

JEL No. F2, L4

\section{$\underline{\text { ABSTRACT }}$}

This paper estimates the effects of several American law firms' international networks of offices on the total value of overseas mergers and acquisitions (M\&A) by US corporations. Nowadays many nations can review proposed mergers and US law firms help clients overcome such regulatory hurdles, effectively greasing the market for corporate control. However, they can also oppose transactions that are inimical to their clients' interests. I present evidence that suggests that Baker \& McKenzie - the US law firm with the most overseas offices - has facilitated such transactions, whereas the combined effect of the next five largest American law firms has tended to reduce such M\&A.

Simon J. Evenett

World Trade Institute

University of Bern and CEPR

Hallerstrasse 6

Bern

Switzerland

simon.evenett@worldtradeinstitute.ch 


\section{Introduction}

In recent years there has been considerable interest in the means by which groups of market participants interact so as to facilitate various forms of international commerce. Particular emphasis has been given in this research program to mechanisms to locate potential buyers and sellers and to overcome contract enforcement problems (Rauch, 2002; and Rauch and Casella, forthcoming). Given the considerable growth in international trade flows since 1985, especially in the pan-Pacific region where Chinese business groups operate extensively, it is perhaps not surprising that research into such mechanisms has gathered pace (see, for example, Rauch and Trindade, 2002.)

The late 1990s witnessed a surge in one form of international commerce that has received considerably less attention from international economists: a global wave of mergers and acquisitions (M\&A). ${ }^{2}$ What is more, since the 1980 s-that is, well before the latest M\&A wave-leading law firms have been expanding their presence outside their home jurisdictions, creating networks of legal professionals to advise corporations as they take advantage of the opportunities afforded by the current era of international market integration. This paper explores whether there is a connection between these two phenomena; that is, whether the formation of such global law firms has helped contribute to overseas US M\&A activity during 1999, one of the boom years in the latest wave of crossborder M\&A.

The causal links between the presence of global legal networks and transactions in the international market for corporate assets are potentially different from those traditionally emphasized in studies of international trade flows; the latter stressing the roles of search costs, asymmetries of information, and contract enforcement costs. A feature of transactions in the market for corporate control is

\footnotetext{
${ }^{2}$ See, however, Evenett (2003) for a detailed overview of the composition and scale of this international wave of M\&A; and an econometric analysis of the impact of such transactions on the banking spreads in selected OECD nations.
} 
that purchases and sales of firms often involve review by and approval by national competition or antitrust authorities. These review processes not only erect a potential barrier to $M \& A$ transactions but they also create demand for the very services of intermediaries-such as law firms and economic consultancies-whose actions may influence the outcome of these official investigations.

In a multi-country world a merger of two firms may require the approval of many national authorities. For example, the merger between Price Waterhouse and Coopers and Lybrand, announced on September 17, 1997, required approval in the United States, by the European Commission, in Canada, Australia, New Zealand, and Switzerland-to name some, and by no means all, of the jurisdictions involved (Kolasky, 2000). Law firms with a global imprint can and do help clients to obtain clearances from national antitrust authorities for mergers and takeovers with international ramifications. Familiarity with both the clients needs and with numerous national merger review procedures are the means by which global law firms can add grease to the international market for corporate assets.

Another feature of merger review procedures is that some jurisdictions appear to give rival firms greater opportunities to present evidence against a proposed merger than others. It is often claimed that the European Commission's merger review procedure gives opponents to a proposed merger a greater role than in comparable U.S. proceedings (Boeder, 2000; Venit and Kolasky, 2000); a point that was made with particular force by some in the aftermath of the European Commission's decisions on the proposed Boeing-McDonnell Douglas and General Electric-Honeywell mergers. To the extent that this is true, global law firms can throw sand into the wheels of this form of international commerce by presenting evidence against proposed transactions that are inimical to their 
clients' interests. ${ }^{3} \mathrm{~A}$ priori, then, it is unclear whether the existence of global legal networks has facilitated or retarded cross-border mergers and acquisitions.

A rich dataset of the overseas presence of 100 US law firms in 1997 is employed here to examine whether their geographical reach across national borders correlates with the pattern of overseas M\&A by US corporations in 1999. Controlling for the other plausible determinants of international M\&A activity (such as distance from the United States, national income and corporate tax rates of the overseas jurisdiction), I examine whether the presence of six large US law firms, which together account for 60 percent of the employment of US lawyers in the foreign countries considered in my empirical analysis, have contributed to the observed level of overseas M\&A activity by US corporations in 1999. In addition, as merger notification requirements and reviews tend to apply more strictly to relatively larger M\&A transactions, I examine whether the presence of these six US law firms increases the mean size of recorded crossborder M\&A transactions.

The principal finding is that the presence in a country of the US law firm with the greatest global footprint (Baker \& McKenzie) substantially raises the total value of US M\&A activity in that jurisdiction. In contrast, the presence in a country of five other US law firms with large overseas operations tends to reduce both the total value and mean size of M\&A transactions in an economy. On net, however, the geographical allocation of these six law firms' offices is such that US M\&A activity into many non-G7 economies, including several relatively fast growing developing economies, is double what would have otherwise occurred. This implies that the global presence of at least one major US law firm has brought

\footnotetext{
${ }^{3}$ It is worth pointing out that relatively few mergers are publicly opposed or rejected by national competition agencies. Often, officials make their opposition known in the early stages of a merger review, so giving the merging parties an opportunity to withdraw their merger. In other cases, officials signal their opposition during informal meetings (or "soundings") before a merger is proposed. Both types of official opposition may well be encouraged by the evidence provided by legal advisers to rivals to the merging parties. In fact, the number of publicly rejected mergers is a fraction of the planned mergers that are not consummated. (How small a fraction, of course, is hard to tell.)
} 
additional pressure on (in particular publicly traded) firms in developing economies to improve their performance. My regression results also imply that nations with merger review procedures tend to receive half of the total value of US overseas M\&A than would have otherwise been the case, suggesting that such legal requirements have considerable bite. (This latter finding is itself quite interesting given the paucity of academic studies of the quantitative impact of merger review laws on the number of national and international mergers and acquisitions. ${ }^{4}$ )

This paper is organized as follows. In the next section I summarize the key aspects of the boom in global M\&A activity in the mid-to-late 1990s, and the growth of US law firms' operations since 1985. In section three, the econometric strategy and data employed are described, as are the estimation results. A discussion of these findings, with suggestions for future research, are presented in section four.

\section{The late 1990s boom in cross-border mergers and acquisitions and the international expansion of US law firms}

The 1990s saw a ten-fold real increase in the value of cross-border mergers and acquisitions. According to OECD (2001), over a trillion US dollars of corporate assets were involved in cross-border M\&A in the year 2000. Unlike the surge in cross-border M\&A in the late 1980s, the latest wave was not confined principally to transactions between British and American firms. Continental European, Japanese, Korean, Latin American, and South East Asian firms played significant roles in what has been termed by some as the first "global" wave of mergers and acquisitions (Black, 2000). Figure 1 provides evidence on the extent of US outward M\&A activity, and shows that US purchases of corporate assets abroad trebled in real terms between 1995 and 1999.

\footnotetext{
${ }^{4}$ For distinct empirical analysis of the effects of merger review regimes see Evenett (2002).
} 
Many factors are said to be responsible for this global wave of M\&A. Deregulation and privatization (especially in the utilities sectors) are important explanations in Europe and in many developing economies (UNCTAD, 2000; OECD, 2001). Changes in corporate strategy, which have emphasized both the concentration on so-called core competencies and attaining global reach, is a contributing factor in manufacturing industries in particular (OECD, 2001). And liberalization of foreign direct investment regimes has no doubt played a role in facilitating overseas acquisitions of corporate assets, as has the ease with which firms were able to raise funds cheaply on stockmarkets in the late 1990s.

These developments have, of course, not gone unnoticed by antitrust officials around the world. As Table 1 makes clear, an increasing share of overseas US M\&A activity involved the acquisition of a majority controlling interest in a foreign firm. In fact, in 1999 nearly two thirds of such M\&A transactions involved acquiring a controlling stake. To the extent that these transactions reduce the number of competitors in a given market ${ }^{5}$, antitrust officials may be concerned about the potential exercise of monopoly power by the remaining firms. ${ }^{6}$ This has undoubtedly contributed to an increase in the number of nations with active programs for merger notification or review. According to an advisory committee to the US government on international competition policy matters, by the year 2000 sixty jurisdictions had some form of mandatory merger notification scheme (ICPAC, 2000, Annex 2-C). ${ }^{7}$ Such schemes are often complemented by review procedures to assess the likely impact on a nation's markets of a proposed or actual transaction. In principle, therefore, a cross-border merger could be

\footnotetext{
${ }^{5}$ One of the ways in which greenfield foreign direct investments and cross-border mergers differ is that the former typically increases the number of firms in a given industry in the recipient economy which, in turn, can result in lower mark ups of prices over costs.

${ }^{6}$ It would be wrong to assume that all antitrust authorities analyze the economic impact of mergers in the same way, as recent disagreements across the North Atlantic between US and European antitrust officials can attest (see the contributions in Evenett, Lehmann, and Steil, 2000). This further adds to the demand for legal intermediaries and puts at a premium the ability to coordinate in a coherent manner merger clearance procedures across many jurisdictions.

${ }^{7}$ The spread of such merger review laws is now so pronounced that one leading U.S. law firm, White \& Case, prepares an annual compilation of national merger review procedures and extensively comments on the latest legal developments in this regard. See White \& Case (2001).
} 
reviewed by many national antitrust authorities; and depending on the statutes governing these authorities' powers, the latter can reject such a proposed merger outright or, as is more common, can demand divestitures or other commitments from the parties involved. In some countries, in particular those with federal constitutions such as the United States, sub-national antitrust authorities may add to the number of reviewing bodies. An interesting question is whether the cumulative effect of these reviews is to erect a considerable barrier to international mergers and acquisitions, that is, to the international trade in corporate assets.

Multi-jurisdictional merger review has considerably expanded the demand for legal services on two accounts. First, firms seeking approval for their proposed M\&A transactions need specialized counsel in (at least) each of the major jurisdictions, and need to coordinate their counsel's responses so that any concessions (or agreements reached with antitrust authorities) do not jeopardize the commercial viability of the transaction. Second, firms opposed to a rivals' announced plans to merge or acquire assets abroad can hire legal counsel to present evidence to antitrust authorities that casts the proposed transaction in a poor light. ${ }^{8}$ Some antitrust legal practitioners refer to this practice as "forum shopping"; the pursuit of jurisdictions that are sympathetic to firms opposed to a merger. Again, such practices often need to be coordinated so as to maximize the probability that a sufficiently large number of antitrust authorities take steps to oppose enough components of a proposed deal that it is eventually abandoned. As noted earlier, the receptiveness of antitrust authorities to evidence presented by rival firms varies considerably across jurisdictions and may well be greater in jurisdictions with nascent or younger merger review procedures.

\footnotetext{
8 It should be noted that there are, in principle, circumstances under which the rivals to two or more merging firms would support-rather than oppose-the proposed merger. A merger between firms in the same market that does not result in lower marginal costs for the merged firm could well benefit rivals as the intensity of competition may well attenuate after the merger.
} 
One supply side response to this increased demand for specialist antitrust counsel in many jurisdictions has been the formation of M\&A practice areas in global law firms. Such firms almost always started out serving either the US or the British national market. As far as US law firms are concerned, Spar (1997) identifies two waves of overseas expansion: 1965-85 and after 1985. The first wave saw US law firms follow their multinational clients abroad. For example, Shearman \& Sterling opened a Paris office in 1967 just as its client Citibank was expanding vigorously overseas. Spar argues that:

"Some of the US firms that went abroad matured past their initial clients, building sizeable independent practices in their new found locations. Most of them, though, did not, and left their overseas posts once their clients' work was completed." (Spar, 1997 page 13)

The second wave was, however, on a larger scale and at the initiative of the law firms themselves. For example, Morrison \& Forrester, a San Francisco-based US law firm, opened a practice in Hong Kong in 1982 without having a single client in the region (Spar, 1997). In this wave, supply tended to lead demand, as Spar notes

"Once a few firms established sizeable international practices, they achieved a critical mass that made them attractive to multinational clients. Rather than asking multinationals to spread their legal advising among a number of far flung firms, multinational law firms could offer coordinated and consolidated service." (Spar, 1997 page 14)

These large global law firms were in place well before the global merger wave took off in the late 1990s. By 1989, the 250 largest US law firms had 180 overseas offices (Spar, 1997). This growth continued through the 1990s. A recent analysis revealed that in 1997 the top 100 US law firms had 363 overseas offices employing 4214 lawyers (Beaverstock, Smith, and Taylor, 2000). One firm 
alone, Baker \& McKenzie, had 1802 of these lawyers on its payroll and operated 48 overseas offices; far exceeding (on these metrics) the global reach of any rival law firm. ${ }^{9}$

While accepting the argument that the overseas offices of US law firms have been established to supply a wide range of services, meeting the expected future needs of clients for advice on mergers and acquisitions has been a prominent rationale for overseas expansion. For example, the law firms of Coudert Brothers; Shearman \& Sterling; Jones, Day, Reavis \& Pogue; Kaye, Scholer, Fierman, Hays \& Handler; and White \& Case are said to have established offices in China during 1993-2000 with mergers and acquisitions stated as important practice areas. ${ }^{10}$

I will now summarize some of the main arguments of this section. Global legal networks expanded before the latest wave of cross-border M\&A. The presence of a man-made impediment to trade in corporate assets-merger review procedures-provides these networks with a means to hamper or to facilitate cross-border M\&A, and distinguishes these networks from the existing literature on business networks which emphasizes the latters' role in promoting international trade in goods and services. The remainder of this paper is devoted to examining whether there is any empirical evidence that the global footprint of several leading US law firms facilitated or reduced US overseas M\&A activity in 1999, a year when the latest wave of global M\&A was in full swing.

\section{Econometric strategy and data employed}

Given that many factors which are unrelated to the presence of legal intermediaries can influence the amount of US cross-border M\&A in a foreign

\footnotetext{
${ }_{10}^{9}$ For an account of the worldwide expansion of Baker \& McKenzie see Bauman (1999).

10 See "Through the Open Door: Top China Outposts," accessed at http://www.law.com/special/professionals/amlaw/global_50/China_chart.html on October 15, 2001.
} 
country, the objective here must be to adequately control for these determinants and to examine how much of the remaining variation is associated with the presence of global legal networks. The first step taken was to assemble the largest possible dataset of economies which received US cross-border M\&A in 1999. Several financial companies track announcements of proposed (and completed) US cross-border M\&A, and here I used the data reported in the 2000 Mergerstat Review. This source reports that 52 overseas economies or territories received US cross-border M\&A in 1999, with a total value of such transactions equaling $\$ 173.5$ billion. Three smaller territories (Bermuda, St. Kitts and Nevis, and Puerto Rico) were excluded from the samples assembled here because they were in fact either U.S. territories or where the reported M\&A data may well be misreported financial transfers (with no corporate assets changing hands.) ${ }^{11}$

I have modified the traditional gravity equation approach to estimating the determinants of international trade flows to quantify the factors responsible for US cross-border M\&A in 1999. As cross-border mergers and acquisitions are a form of foreign direct investment (FDI), my approach is not too different to the many gravity-based studies of FDI flows; see, for example, Levy Yeyati, Stein, and Duade (2002). However, as will become clear, I include many more mergerspecific variables in my econometric analysis than are typically found in FDI studies.

The gravity equation approach posits that the value of the economic transactions between two entities depends on each body's economic mass and the distance between them (Anderson, 1979, Deardorff, 1998, and Evenett and Keller, 2002.) In this context, this amounts to assuming that the distance between a foreign nation and the United States and the former's national income are candidate

\footnotetext{
${ }^{11}$ Eliminating these three territories leaves 49 economies in my dataset. The 49 economies are: Argentina, Australia, Austria, Bahrain, Belgium, Brazil, Canada, Chile, China, Costa Rica, the Czech Republic, Denmark, the Dominican Republic, Egypt, El Salvador, Finland, France, Germany, Ghana, Hong Kong PRC, Hungary, India, Indonesia, Ireland, Israel, Italy, Japan, Lithuania, Malaysia, Mexico, Netherlands, New Zealand, Norway, Pakistan, Peru, the Philippines, Poland, Portugal, Romania, Singapore, South Africa, Korea, Spain, Sweden, Switzerland, Taiwan, Thailand, the United Kingdom, and Venezuela.
} 
determinants of the total value of US cross-border M\&A taking place in that nation. ${ }^{12}$ The intuition is that a larger foreign market provides, other things being equal, greater sales opportunities for US firms and their subsidiaries; and that greater distance from the United States makes running a foreign subsidiary or acquisition more difficult and so detracts from the desirability of buying or merging with that nation's firms. Data on the 49 economies' gross domestic products was taken from the World Bank's World Development Indicators CDROM. Following standard practice, the distance from Washington, D.C., to the administrative capital of each economy was used as the proxy for distance from the United States.

Three other control variables were employed. The first is a proxy for the retained corporate profit rate (that is, the proportion of a firm's profits that it can expect to keep after paying taxes and other government-assessed fees and levies.) Economies which have higher retained profit rates are hypothesized to be more desirable places to undertake cross-border M\&A. I proxy for this rate with one minus the maximum corporate tax rate charged in an economy, which too is available in the World Development Indicators database. The second control variable is the foreign economy's tariff rate. The logic here is that higher tariffs reduce the profitability of exporting to an economy and enhance the attractiveness of establishing local subsidiaries. However, an alternative hypothesis is that national tariff rates proxy for the degree of policy-induced internal and external distortions to an economy, and to the extent that such internal distortions reduce the profitability of firms, this will discourage crossborder M\&A. ${ }^{13}$ I took the average tariff rate as the proxy for the restrictiveness of a nation's trade barriers, data which too is available on the World Development

\footnotetext{
${ }^{12}$ Strictly speaking the gravity equation approach suggests that the level of US national income is a determinant too of the value of outward US cross-border M\&A. However, the fact that my dataset contains information on such cross-border M\&A transactions for one year (1999) means that the level of US national income cannot account for the variation in the value of M\&A received across different foreign economies. Consequently, I do not include US national income as an explanatory variable in my econometric analysis.

${ }^{13}$ In the context of the cross-country growth literature, Xavier Sala-I-Martin has forcefully argued that national tariff rates can proxy for both internal and external barriers to economic exchange.
} 
Indicators CD-ROM. The final control variable is whether a country has a British colonial heritage. This could be important for two reasons. First, in an economy with such a heritage English is more likely to be the language of business, making it easier for a US firm to run any corporation it acquires in that economy. Second, the likelihood that an economy has a common law system is greater if it was at some point a British colony-and this is precisely the system that operates in the United States and is familiar to US lawyers. Both conjectures suggest that having a British colonial heritage will raise the amount of US crossborder M\&A. A dummy variable is introduced to capture this effect (taking the value of one if the economy has such a heritage.)

The first antitrust-related variable employed in the empirical analysis is whether the foreign economy has a merger notification scheme or merger review procedure. As argued in the last section, such schemes and reviews are likely to reduce the amount of cross-border M\&A, especially for larger transactions. Even though merger notification regimes and review procedures vary considerably across nations, I employ a dummy variable to indicate whether a nation has such a regime or not. ${ }^{14}$ The list of economies taken to have such regimes in 1999 was assembled from ICPAC (2000, Annex 2-C) and from statements on the web pages of the U.S. Department of Justice's Antitrust Division and the Competition Directorate-General of the European Commission. In our sample of 49 economies, the following were found not to have some form of merger review regime in 1999: Ghana, Pakistan, Egypt, El Salvador, China, Indonesia, Malaysia, the Dominican Republic, Singapore, and Hong Kong, PRC.

Before describing the first econometric specification employed it will be helpful to introduce the following notation:

\footnotetext{
${ }^{14}$ One conference participant suggested that all of the EU members in my sample should be aggregated into a single entity because mergers in these economies can be, in principle, reviewed by a single body (the European Commission). While it is the case that these EU members are similar in this respect, the values of the control variables (such as distance, retained corporate tax rates, and alike) differ markedly across these economies; and such variation is helpful in identifying the effect of such control variables on cross-border M\&A. It is also the case that some of the mergers in EU economies are reviewed by national competition authorities.
} 
$M_{i} \quad$ Denotes the total value of US cross-border M\&A into economy $i$ in 1999.

$\mathrm{ma}_{\mathrm{i}} \quad$ Denotes the mean value of US cross-border M\&A into economy $\mathrm{i}$ in 1999.

$\mathrm{GDP}_{\mathrm{i}} \quad$ Denotes the value of gross domestic product of economy $i$ in 1999, measured in US dollars.

DIST $_{i} \quad$ Denotes the distance of economy i's capital from the Washington, D.C., in kilometers.

$\pi_{i} \quad$ Denotes the retained corporate profit rate in economy i.

$\left(1+t_{i}\right) \quad$ Denotes one plus economy i's average tariff rate on imported goods.

BRIT $_{i} \quad$ Denotes a dummy variable which equals one if economy $i$ has a British colonial heritage.

$\mathrm{MN}_{\mathrm{i}} \quad$ Denotes a dummy variable which equals one if economy $\mathrm{i}$ has a mandatory merger notification regime or a merger review procedure in 1999.

$e_{i} \quad$ Denotes a random error term, assumed to have zero mean and finite variance.

c Denotes a constant.

The first two specifications estimated were:

$\ln \left(M A_{i}\right)=c+\beta_{1} \ln \left(G D P_{i}\right)+\beta_{2} \ln \left(D I S T_{i}\right)+\beta_{3} \ln \pi_{i}+\beta_{4} \ln \left(1+t_{i}\right)+\beta_{5} B R I T_{i}+\beta_{6} M N_{i}+e_{i}$ $\ln \left(m a_{i}\right)=c+\beta_{1} \ln \left(G D P_{i}\right)+\beta_{2} \ln \left(D I S T_{i}\right)+\beta_{3} \ln \pi_{i}+\beta_{4} \ln \left(1+t_{i}\right)+\beta_{5} B R I T_{i}+\beta_{6} M N_{i}+e_{i}$

where $\ln (\mathrm{X})$ is the natural logarithm of a variable $\mathrm{X}$ and $\beta_{1}, \ldots, \beta_{6}$ are parameters to be estimated. The first specification takes the total value of US cross-border M\&A as the dependent variable, and the second specification takes the mean value of US cross-border M\&A as the dependent variable. Concerns about heteroskedacity which are common in cross-sectional samples (such as the ones analysed here) resulted in a two step estimation procedure being employed. In the first step, each specification was estimated using ordinary least squares and the absolute value of the regression residuals $\overline{e_{i}} \mid$ were recovered. The latter were used to weight each observation and the specifications were re-estimated. The full set of parameter estimates and their associated p-values are reported in 
Table 2 for the regression with the total value of M\&A activity as the dependent variable, and in Table 3 for the specification where the mean value of M\&A transactions was the dependent variable.

Examining the third and fourth columns of these two tables it is clear that the controls have, by and large, their expected signs. Richer economies that are closer to the United States, which have lower corporate tax rates and a British colonial heritage, tend to attract more US M\&A. The large negative estimated parameter on the tariff terms suggests that they are most likely proxying for the extent of internal as well as external distortions to an economy and, on net, repel US M\&A. As these control variables have little bearing on the main question at hand, and because their estimated parameters do not vary much across the specifications discussed below, I shall not discuss them further. In specification 1 , the presence of a merger notification regime does not appear to influence the total value and mean value of US cross-border M\&A. I will return to this finding later.

To examine the effect of the presence of American legal networks on US crossborder M\&A in 1999, I employed Beaverstock, Smith, and Taylor's (2000) dataset of the location of the overseas offices of the top 100 US law firms for the single year 1997. What this remarkably detailed dataset lacks in the intertemporal dimension is largely compensated for by its rich cross-sectional variation, which I exploit here. Their database indicates that in the 49 economies in my samples there were 4066 lawyers working overseas for these law firms. Further analysis revealed that 60 percent of those lawyers worked in just six US law firms: Skadden, Arps, Slate, Meagher \& Flom; Jones, Day, Reavis \& Pogue; Shearman \& Sterling; Coudert Brothers; White \& Case; and Baker \& McKenzie (see Table 4.) The vast scale of Baker \& McKenzie's overseas operations is apparent-this US law firm operated in 30 of the 49 economies in my sample and employed 1743 lawyers (see Table 4 and Figure 2). For the purposes of exposition I refer to these six US law firms as the "Big 6" firms, and the goal of the remaining 
empirical analysis is to estimate the contribution of the presence of these six legal networks within a jurisdiction to the amount of US M\&A that takes place in that jurisdiction.

It is important to differentiate between the presence of these six law firms and the number of lawyers employed by US firms in a foreign economy. Even though the object of interest here is the effect of the former, the latter may well provide an imperfect indicator of the capacity of US law firms to represent their clients interests in an given overseas jurisdiction. In my initial attempt to sort out the independent contribution of the Big Six, I proceeded as follows. First, I computed the total number of lawyers hired by US firms in each of the 49 economies in my samples, and the number of Big Six firms that had over 10 lawyers in any given economy. (Requiring that there be 10 or more lawyers hopefully rules our smaller overseas offices which are unlikely to have M\&A practice areas. ${ }^{15}$ ) Specifications 2 and 3 in Table 2 and 3 report the parameter estimates when the (natural logarithm) of the number of US lawyers and the number of Big Six firms are included as independent variables. Consistent with the hypothesis that the effect of such lawyers and legal networks on cross-border M\&A is only due to the presence of merger notification requirements and review procedures, I interact these two new independent variables with the dummy variable indicating the presence of a merger notification regime $\left(\mathrm{MN}_{\mathrm{i}}\right)$. Including the number of Big Six firms causes the estimated parameter on the number of US lawyers to turn negative and statistically significant (at the 10 percent level)—suggesting that the net effect of having more lawyers employed by US firms in a foreign economy is to reduce the sale of that economy's assets to US corporations. As both tables make clear, the number of Big Six firms in an economy does not appear to independently influence either the total value or the mean value of US crossborder M\&A.

\footnotetext{
${ }^{15}$ I relaxed this requirement to five lawyers and found that it had no substantial effect on the estimated results or qualitative findings.
} 
One objection to specification 3, which includes both the number of US lawyers and Big Six firms as independent variables, is that the former is likely to be larger in precisely those economies where the Big Six firms are present. Consequently, the independent variable for the number of US lawyers may well be absorbing some of the explanatory power of the variable that records the number of Big Six firms present. To address this problem, I purged the former variable of any variation accounted for by the latter variable, effectively creating an instrument for the number of US lawyers in an economy that is, by construction, orthogonal to the number of Big Six legal firms present. Specification 4 reports the parameter estimates which result from using this instrument. Interestingly, the number of American lawyers still has a negative and statistically significant effect on the amount of US cross-border M\&A received. The number of the Big Six law firms in an economy is found to depress the mean value of cross-border M\&A but not the total value of such M\&A-suggesting that these firms are successful in blocking larger cross-border M\&A transactions (or deterring their announcement in the first place.) Another interesting finding in specification 4 , is that the estimated coefficient for the presence of a merger notification regime turns negative (but is not statistically significant at any recognized level.)

Given the difference in scale of Baker \& McKenzie's global network from the other members of the Big Six, a question arises as to whether the effect of the former's network differs from those of the other five legal networks that I have identified. One hypothesis of interest is that obtaining clearance for a merger in many jurisdictions increases the demand for the services of global law firms with a very wide reach, such as Baker \& McKenzie. Whereas, attempting to frustrate a rival's plans to merge may only require the services of a global law firm with offices in key (larger) jurisdictions, such as the other members of the Big $6 .{ }^{16}$ If this hypothesis is correct, one might expect to see the presence of Baker \& McKensie to increase the mean size of the M\&A transactions undertaken within a jurisdiction by more than the presence of any of the other five legal networks.

\footnotetext{
${ }^{16}$ I thank Kyoji Fukao for succinctly crystallizing the issue is this manner.
} 
Moreover, to the extent that the other five legal networks play a substantial role in persuading competition authorities to block larger proposed M\&A transactions, then the mean size of such transactions may well fall.

To investigate this matter further, I have dropped the number of Big Six firms as an independent variable, and included a separate dummy variable for the presence of a Baker \& McKenzie office in an economy (again with 10 or more lawyers) and an independent variable for the number of the other Big Six firms in an economy. ${ }^{17}$ The results are reported as specification 5 in Tables 2 and 3. Interestingly, the inclusion of these terms produces-for the first time-negative and statistically significant coefficients for the presence of a merger notification scheme. The latter coefficients imply that merger review procedures reduce the mean value of US M\&A transactions by approximately 50 percent, a sizeable economic impact.

The inclusion of these two network terms in specification 5 does suggest that these global legal networks significantly affect the extent of US cross-border M\&A. It appears that having a large Baker \& McKenzie office in a country substantially boosts the total value of US cross-border M\&A in that country, but does not increase-at any recognized level of statistical significance-the mean value of such M\&A transactions. In contrast, the effect of the presence of the other Big Six firms reduces the total value and the mean value of cross-border M\&A undertaken by US corporations in a jurisdiction. The parameter estimates in table 2 imply that the presence of each of these other five legal networks is to reduce the total value of such $M \& A$ by approximately 32 percent. This finding is consistent with the explanation that the M\&A practices of these five US law firms have earned their spurs in part by frustrating the expansion plans of the rivals to their US clients. An alternative explanation is that to sustain their large overseas

17 One alternative approach I considered was to include separate dummy variables for the presence of each of the Big Six firms. It turns out that there is significant collinearity between the dummy variables for the five smaller members of the Big Six, which means the estimated effect for each dummy variable would have been identified off at most a handful of countries-a highly unsatisfactory basis upon which to make inferences. 
offices, these law firms have begun to defend local firms against US takeovers. My results also imply that the presence of Baker \& McKensie's global network of offices has only been to increase the number of small and medium sized crossborder M\&A transactions by US firms. Finally, in unreported results these findings appear to be robust to other corrections for heteroskedacity and to sample composition (outliers.)

A better sense of the net effect of these six legal networks on US cross-border M\&A can be found in Table 5. Using the estimated parameters in specification 5, and taking account of the appropriate covariances, I recovered the combined effect on each economy's receipt of US cross-border M\&A of the presence of all six networks. At the 10 percent level (with one tailed tests), I found that all of the statistically significant estimates are positive-suggesting that on net these networks grease international transactions in corporate assets. What is more, the effects are particularly pronounced in non-G7 economies, including developing economies such as Brazil, Chile, Hungary, the Philippines, Thailand, and Venezuela; a reflection of the fact that such nations have Baker \& McKenzie offices and few (or no) large offices from the other Big Six firms. To the extent that such overseas M\&A brings pressure on domestic firms in these economies to improve performance, then this may well be a positive development. ${ }^{18}$ Of course, to the extent that such M\&A reduces competition in those nations' markets then the effects may not be so benign.

\section{Summary and implications for future research}

Much of the existing literature on the effects of networks on trade has emphasized the trade-facilitating aspects of network formation. In this paper I have considered the effects of global legal networks where a proiri one cannot be certain that their presence has greased the wheels of one form of international

\footnotetext{
${ }^{18}$ This finding would also reinforce the case for liberalizing any restrictions on the entry of foreign legal firms.
} 
commerce, cross-border mergers and acquisitions. The existence of merger notification requirements and merger reviews provides a law firm with an opportunity to present evidence that might go some way to convincing antitrust authorities to oppose (or to demand changes to) a transaction proposed by a rival to the law firm's clients. I have presented evidence to suggest that for five US law firms with sizeable global reach this is, on net, exactly the consequence of their international presence.

There are a number of important caveats to my analysis which should be borne in mind when interpreting the results. First, I am dissatisfied with the use of a single dummy variable to estimate the effects of merger review and notification procedures. These procedures do differ across economies and may have distinct effects. Second, given that not every overseas office (even those with 10 or more lawyers) of a US law firm may not be engaged in advising clients on cross-border M\&A, my measure of each of the Big Six's global reach could with better data be improved upon. Third, the cross-sectional analysis presented does not shed any light on how the impact of these global legal networks has changed over time-a deficiency that could too be remedied by a substantial investment in data collection. One alternative might be to find time-varying instruments for the presence of legal networks. Reflection suggests that this may not be as straightforward as it might first appear; for example, one candidate instrumentsuch as the type of the legal system (common law versus others)-varies a lot across countries but little over time. Fourth, although the focus here has been on the presence of US law firms abroad, one should be open to the possibility that this is correlated with the presence of other service sector firms that facilitate cross-border M\&A, such as investment banks. ${ }^{19}$ Having said this, it is unclear to me why the global reach of the latter would be correlated with the M\&A-reducing effects of the presence of five of the Big 6 law firms studied here. Finally, it is worth reiterating that there is no clear mapping from the value of US M\&A a nation receives and changes in its economic well-being. As discussed at the end

\footnotetext{
${ }^{19}$ I thank Takeo Hoshi for this important observation.
} 
of the last section, cross-border M\&A can enhance or worsen the allocation of a nation's resources. The goal of this paper was, however, far more modest-to examine the positive impact of the presence of six large US legal networks. 


\section{References}

Anderson, James. (1979). "A Theoretical Foundation For The Gravity Equation," American Economic Review, 69(1): 106-116.

Bauman, Jon. (1999). Pioneering a Global Vision: The Story of Baker \& McKensie. Harcourt Professional Educational Group: Chicago, IL.

Beaverstock, J.V., R.G. Smith, and P. J. Taylor (2000). "Geographies of Globalizatoin: US Law Firms in World Cities," Urban Geography, 21(2):95-120.

Black, Bernard S. (2000). "The First International Merger Wave (and The Fifth and Last US Wave)," University of Miami Law Review 54: 799-818.

Boeder, Thomas L. (2000). "The Boeing-McDonnell Douglas Merger," in Simon J. Evenett, Alexander Lehmann, and Benn Steil (eds). Antitrust Goes Global. The Brookings Institution Press: Washington, D.C.

Deardorff, Alan V. (1998) "Determinants of Bilateral Trade: Does Gravity Work in a Neoclassical World?" in Jeffrey Frankel (ed). The Regionalization of the World Economy. University of Chicago Press for NBER: Chicago, IL.

Evenett, Simon J. (2002). "How Much Have Merger Review Laws Reduced Cross Border Mergers and Acquisitions?" In William K. Rowley (ed.) International Merger Control: Prescriptions for Convergence, September 2002.

Evenett, Simon J. (2003). "The Cross Border Mergers and Acquisitions Wave Of The Late 1990s." Paper presented at the CEPR-NBER International Seminar on International Trade.

Evenett, Simon J., Alexander Lehmann, and Benn Steil (eds). (2000). Antitrust Goes Global. The Brookings Institution Press: Washington, D.C.

Evenett, Simon J., and Wolfgang Keller (2002). "On Theories of the Gravity Equation," Journal of Political Economy.

International Competition Policy Advisory Committee (ICPAC) (2000). Final Report. US Government Printing Office: Washington, D.C.

Kolasky, William J. (2000). "Pricewaterhouse Coopers" in Simon J. Evenett, Alexander Lehmann, and Benn Steil (eds). Antitrust Goes Global. The Brookings Institution Press: Washington, D.C.

Levy Yeyati, Eduardo, Ernesto Stein, and Christian Duade. (2002). "Regional Integration and the Location of FDI." Paper presented at the IDB-Harvard Conference on Regional Integration and the FTAA. May.

Mergerstat. (2000) 2000 Mergerstat Review. Houlihan, Lokey, Howard \& Zukin.

Organisation for Economic Cooperation and Development (OECD) (2001). New Patterns of Industrial Globalisation: Cross-border Mergers and Acquisitions and Strategic Alliances. OECD: Paris. 
Rauch, James. (2002). "Business and Social Networks in International Trade." Journal of Economic Literature. 39: 1177-1203.

Rauch, James, and Alessandra Casella. (forthcoming). "Overcoming Informational Barriers to International Resource Allocation: Prices and Ties," Economic Journal.

Rauch, James, and Vitor Trindade. (2002). "Ethnic Chinese Networks in International Trade." Review of Economics and Statistics. 84: 116-130.

Spar, Deborah. (1997). "Lawyers Abroad: The Internationalization of Legal Practice," California Management Review. 39(3): 8-28.

United Nations Conference on Trade and Development (UNCTAD). (2000). World Investment Report. United Nations: Geneva.

Venit, James S., and William J. Kolasky. (2000)."Substantive Convergence and Procedural Dissonance in Merger Review," Chapter 4 of Simon J. Evenett, Alexander Lehmann, and Benn Steil (eds). Antitrust Goes Global. The Brookings Institution Press: Washington, D.C.

White \& Case. (2001). Worldwide Antitrust Merger Notification Requirements. Washington, D.C. 


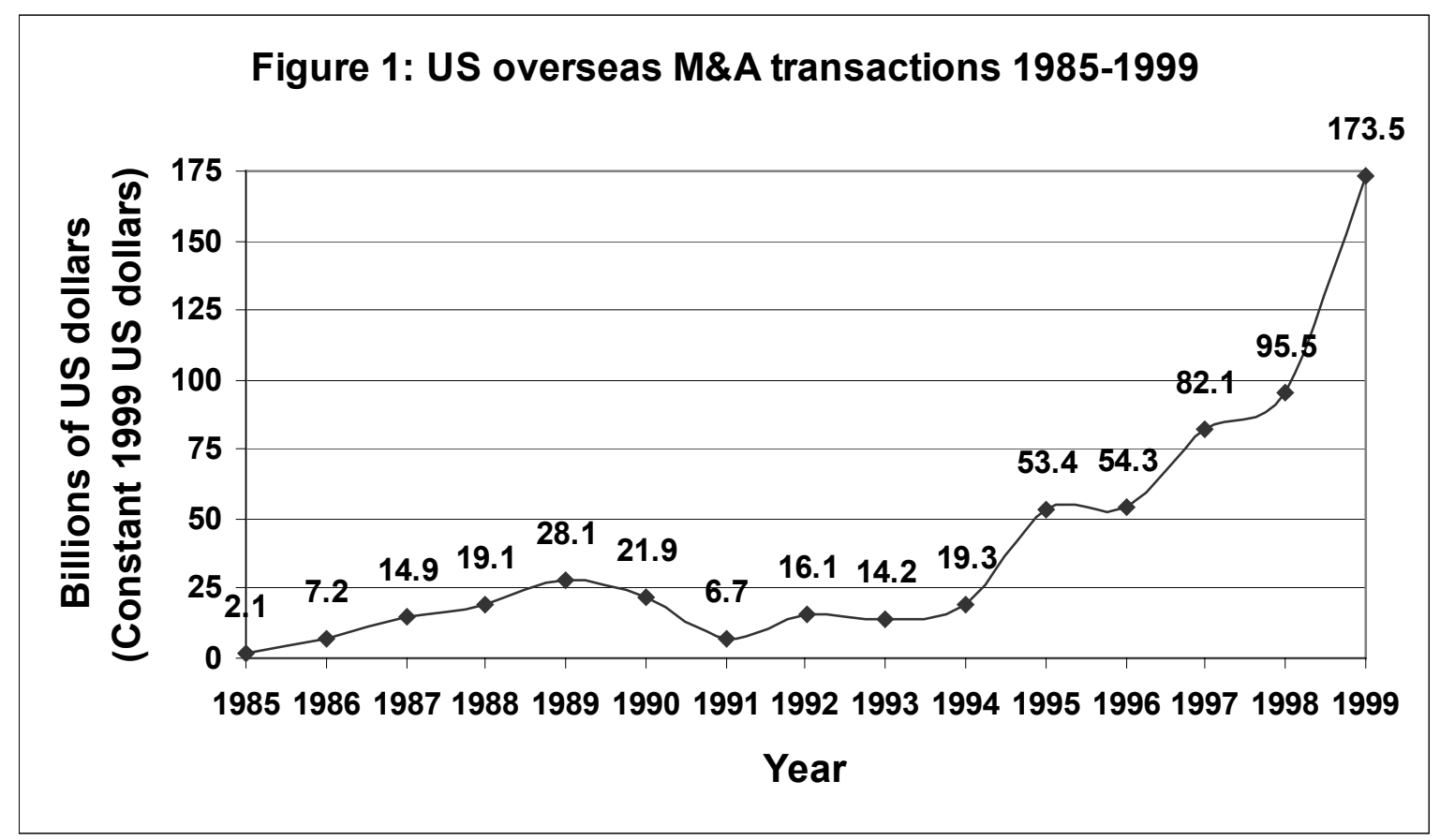

Figure 2: The Big 6 law firms dominate overseas activities by US law firms, measured by number of lawyers in 1998

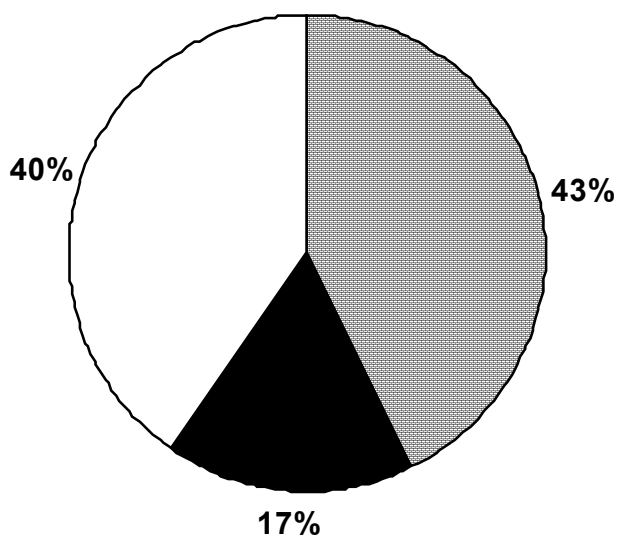

Baker \& McKenzie $\square$ Other Big 6 firms $\square$ Non-Big 6 firms 
Table 1: Types of U.S. overseas mergers and acquisitions

\begin{tabular}{|c|c|c|c|c|c|}
\hline Year & $\begin{array}{c}\text { Acquisition of } \\
\text { controlling } \\
\text { interests }\end{array}$ & $\begin{array}{c}\text { Acquisition of } \\
\text { minority interests }\end{array}$ & $\begin{array}{c}\text { Divestitures of } \\
\text { foreign-based } \\
\text { units }\end{array}$ & $\begin{array}{c}\text { Diverstitures of } \\
\text { US-based units }\end{array}$ & Total \\
\hline \multicolumn{5}{|c|}{ Number of deals } \\
\hline 1990 & 128 & 23 & 57 & 58 & 266 \\
\hline 1995 & 254 & 54 & 94 & 81 & 483 \\
\hline 1999 & 882 & 48 & 309 & 159 & 1398 \\
\hline \multicolumn{5}{|c|}{ Percentage of deals } \\
\hline 1990 & 48.1 & 8.6 & 21.4 & 21.8 & 100.0 \\
\hline 1995 & 52.6 & 11.2 & 19.5 & 16.8 & 100.0 \\
\hline 1999 & 63.1 & 3.4 & 22.1 & 11.4 & 100.0 \\
\hline
\end{tabular}

Source: Mergerstat (2000). 


\begin{tabular}{|c|c|c|c|c|c|c|c|c|c|c|c|}
\hline & & \begin{tabular}{|l|l}
$\frac{8}{g}$ \\
\end{tabular} & 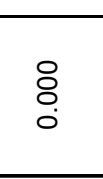 & $\frac{1}{8}$ & $\begin{array}{l} \\
\end{array}$ & $\bar{g}$ & & & & \begin{tabular}{|l|l|}
$\frac{3}{3}$ \\
\end{tabular} & \\
\hline & & $\mid \frac{\Xi}{\Xi}$ & $\frac{1}{3}$ & 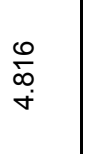 & 8 & 章 & & 昜 & $\bar{s}$ & $\frac{9}{8}$ & \\
\hline & 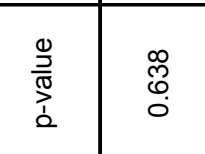 & 气气 & $\frac{1}{8}$ & $\stackrel{8}{8}$ & \begin{tabular}{l|l}
$z$ & $\frac{z}{\partial}$ \\
\end{tabular} & \begin{tabular}{|l}
$\frac{2}{3}$ \\
\end{tabular} & & $\mid 8$ & & & \\
\hline & & ֶֻ & 高 & $\stackrel{s}{s}$ & 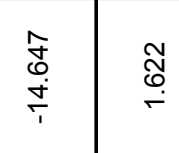 & \begin{tabular}{|l|l} 
\\
\end{tabular} & & 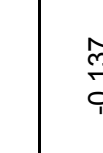 & & & \\
\hline & 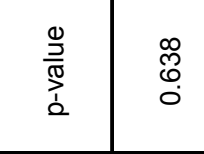 & & 亏 & s. & 8 & 言 & & & & & \\
\hline & $11 \frac{8}{8}$ & & $\begin{array}{l}5 \\
15\end{array}$ & 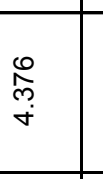 & 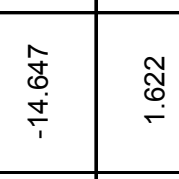 & 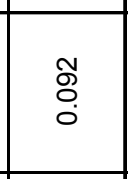 & & & & & \\
\hline & & 气 & ริ & $\frac{1}{2}$ & 气ั 气 & 兽 & $\frac{8}{8}$ & & & & \\
\hline & & 害 & 章 & 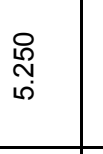 & 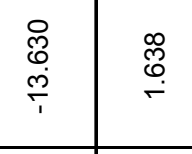 & 害 & s. & & & & \\
\hline & $\begin{array}{ll}3 \\
1\end{array}$ & 气 & ร & s. & 亏ั่ & $\frac{8}{8}$ & & & & & \\
\hline & 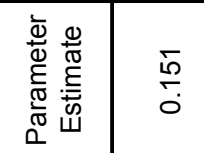 & & $\frac{\not}{p}$ & & $\begin{array}{l}\bar{z} \bar{z} \\
\bar{z}\end{array}$ & 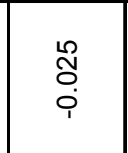 & & & & & \\
\hline & 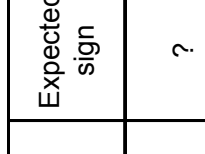 & & & & - & & & & & & \\
\hline & 11 & & & & & & & & & $\sqrt{11}$ & \\
\hline
\end{tabular}




\begin{tabular}{|c|c|c|c|c|c|c|c|c|c|c|}
\hline & & & & & & $\frac{8}{8}$ & & & & 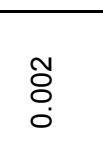 \\
\hline & & 类 & $\frac{\partial}{\partial}$ & $\frac{2}{8}$ & $\stackrel{8}{8}$ & $\frac{.}{\bar{q}}$ & & 䔞 & $\frac{8}{\partial}$ & $\frac{9}{y_{q}}$ \\
\hline & | & : & $\overline{5}$ & š & 8 & 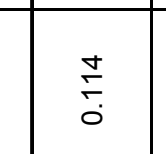 & & ๕ & & \\
\hline & $\tilde{n}$ & $\frac{g}{8}$ & $\stackrel{8}{8}$ & 5 & 8 & $\frac{1}{3}$ & & $\frac{5}{9}$ & & \\
\hline & $\mid$ & ร & 5 & ริ & 8 & $\frac{1}{8}$ & & & & \\
\hline & 1 & : & : & 5 & 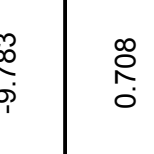 & $\frac{1}{9}$ & & & & \\
\hline & 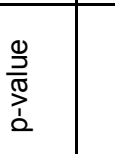 & : & : & 亏 & ริ & $\frac{1}{8}$ & 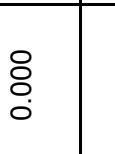 & & & \\
\hline & 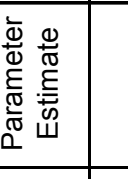 & $\frac{\mathrm{g}}{\mathrm{g}}$ & $\frac{5}{8}$ & 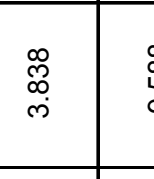 & $\frac{g}{g}$ & 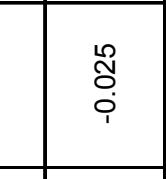 & 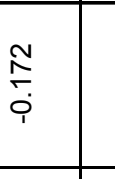 & & & \\
\hline & 1 & $\frac{8}{8}$ & $\frac{g}{8}$ & & 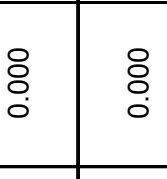 & : & & & & \\
\hline & 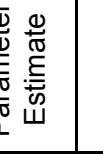 & $\frac{\mathscr{g}}{5}$ & $\stackrel{8}{\circ}$ & $\frac{ \pm}{8}$ & $\frac{z}{2}$ & $\frac{8}{8}$ & & & & \\
\hline & 要 & & & 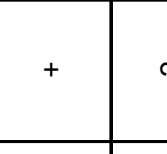 & 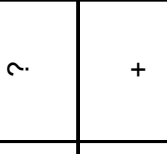 & & & & & \\
\hline & & & & & & & & & & \\
\hline
\end{tabular}




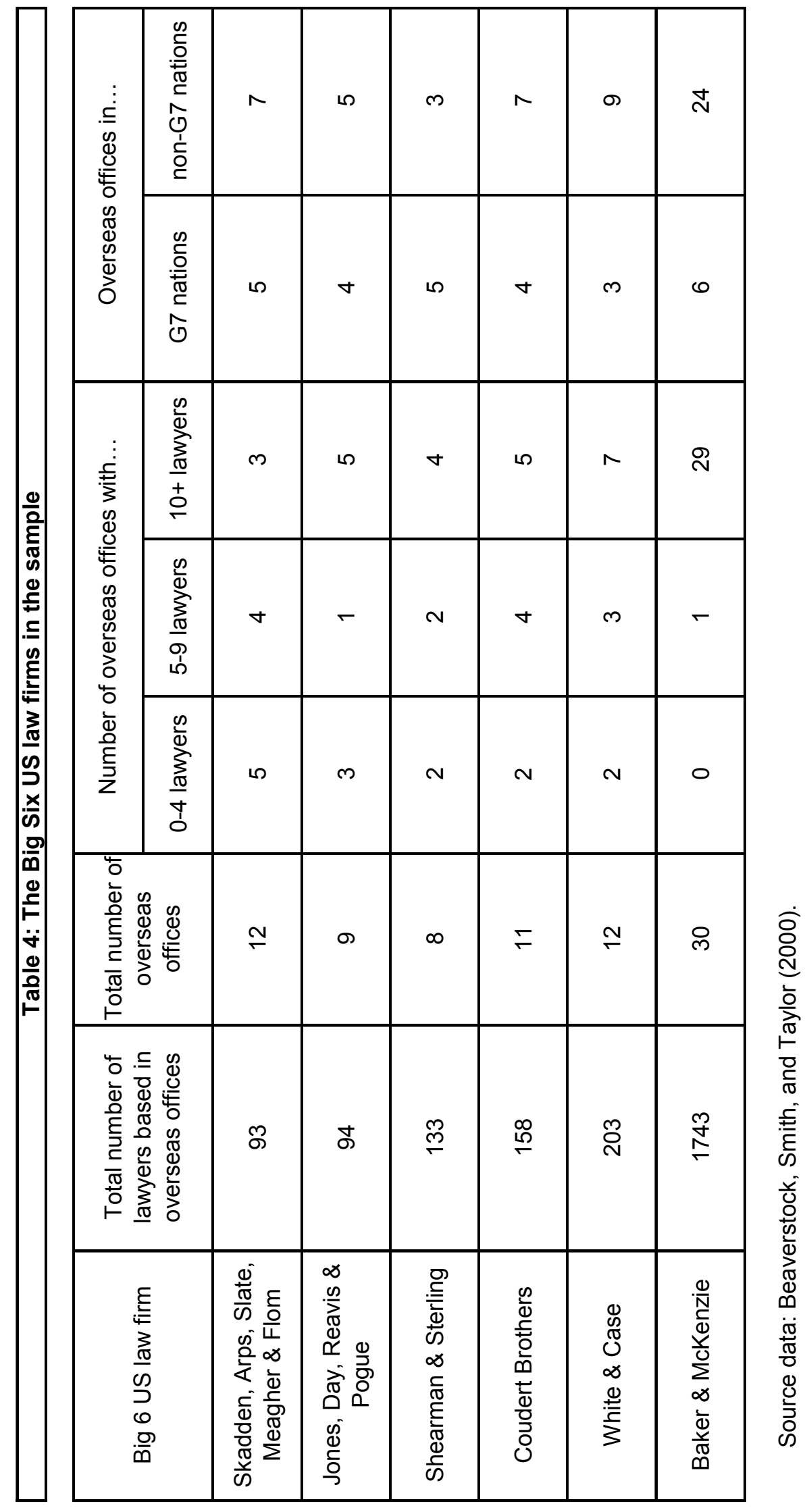




\begin{tabular}{|c|c|c|c|c|c|c|c|c|c|c|c|c|c|c|c|c|c|c|c|c|c|}
\hline \multirow{4}{*}{ 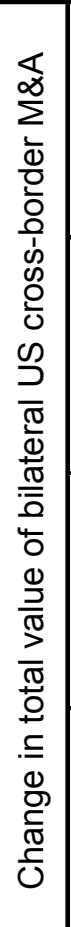 } & 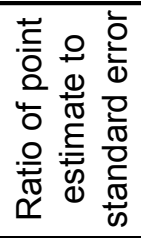 & 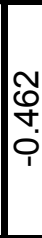 & 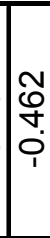 & & 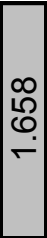 & & & & & $\begin{array}{c}\check{\sigma} \\
\dot{\sigma} \\
\dot{\sigma}\end{array}$ & $\begin{array}{c}\check{c} \\
\dot{\sigma} \\
\end{array}$ & $\begin{array}{c}\tau \\
\varnothing \\
\dot{\sigma}\end{array}$ & & 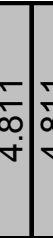 & 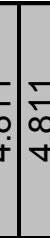 & 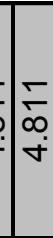 & & $\mid \begin{array}{c}\mp \\
\infty \\
\dot{\nabla}\end{array}$ & & & \\
\hline & 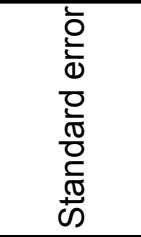 & $\mid \begin{array}{l}\infty \\
0 \\
0 \\
0 \\
0\end{array}$ & $\left\{\begin{array}{l}2 \\
\infty \\
0 \\
0\end{array}\right.$ & 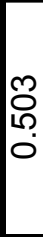 & $\mid \begin{array}{l}\text { m } \\
0 \\
0 \\
0\end{array}$ & 令 & 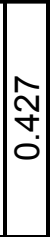 & 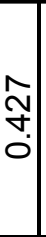 & & $\begin{array}{c}m \\
m \\
m \\
0 \\
0\end{array}$ & $\begin{array}{c}m \\
m \\
m \\
0\end{array}$ & $\begin{array}{c}\text { m. } \\
\text { m. } \\
0 \\
0\end{array}$ & 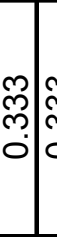 & 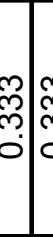 & $\vec{m}$ & : & & $\left|\begin{array}{c}m \\
m \\
m \\
0\end{array}\right|$ & $\begin{array}{c}m \\
m \\
m \\
\vdots\end{array}$ & & \\
\hline & 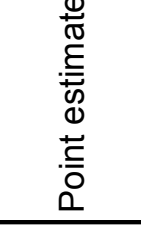 & $\begin{array}{l}0 \\
m \\
0 \\
i\end{array}$ & 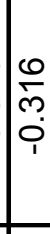 & & $\begin{array}{l}\text { J } \\
\infty \\
\infty \\
0\end{array}$ & $\mid \frac{\infty}{\stackrel{\infty}{\sim}}$ & $\stackrel{\infty}{\sim}$ & $\stackrel{\infty}{\sim}$ & & & & & & حَ' & 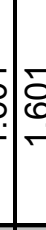 & $\mid \begin{array}{c} \\
\end{array}$ & & $\mid$\begin{tabular}{c}
$\check{0}$ \\
0 \\
\hdashline \\
-
\end{tabular} & & & \\
\hline & 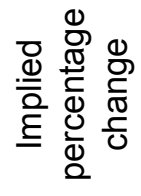 & 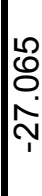 & $\begin{array}{l}0 \\
0 \\
0 \\
\\
\end{array}$ & 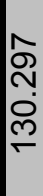 & 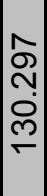 & $\left|\begin{array}{c}m \\
\infty \\
\infty \\
\hat{n} \\
N\end{array}\right|$ & $\mid \begin{array}{c}n \\
\infty \\
\infty \\
\tilde{N} \\
\tilde{N}\end{array}$ & 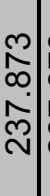 & & & & $\begin{array}{l}\text { 유 } \\
0 \\
\text { ஸి. } \\
\text { లి }\end{array}$ & 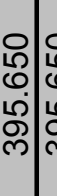 & 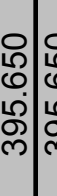 & 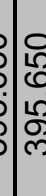 & bे & & 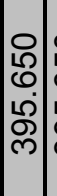 & & & \\
\hline \multirow{4}{*}{ 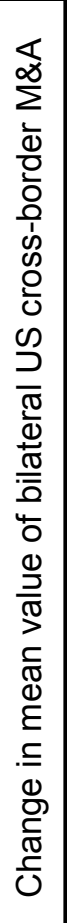 } & 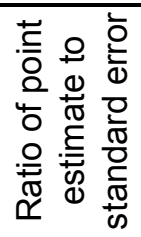 & 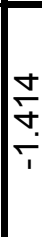 & 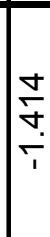 & $\frac{\text { F }}{\stackrel{\text { Th }}{i}}$ & 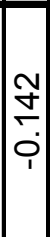 & $\left|\begin{array}{c}\hat{0} \\
0 \\
0 \\
0\end{array}\right|$ & & & & & & & 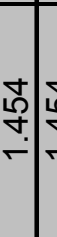 & 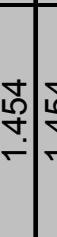 & : & 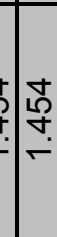 & & & & & \\
\hline & 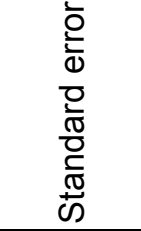 & ִ. & 它 & 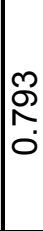 & 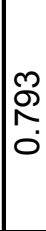 & $\mid \begin{array}{l}0 \\
0 \\
0 \\
0\end{array}$ & $\mid \begin{array}{l}0 \\
8 \\
0 \\
0\end{array}$ & & & & $\mid$ & $\left|\begin{array}{|}1 \\
0 \\
0 \\
0 \\
0\end{array}\right|$ & & 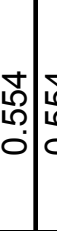 & 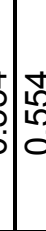 & 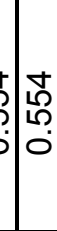 & & $\left.\mid \begin{array}{c}0 \\
1 \\
0 \\
0 \\
0\end{array}\right]$ & & & \\
\hline & 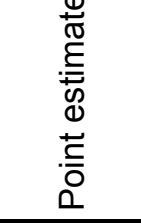 & 吕 & 杵 & $\frac{m}{\frac{m}{c}}$ & $\frac{m}{\frac{m}{c}}$ & $\begin{array}{l}\hat{f} \\
\mathrm{~m} \\
0\end{array}$ & 每 & $\begin{array}{l}\text { యे } \\
\text { mి } \\
0\end{array}$ & 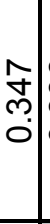 & $\begin{array}{l}0 \\
0 \\
\infty \\
0 \\
0\end{array}$ & $\begin{array}{c}8 \\
8 \\
\infty \\
0\end{array}$ & $\left|\begin{array}{c}8 \\
\varnothing \\
\infty \\
0 \\
0\end{array}\right|$ & $\begin{array}{l}0 \\
\stackrel{0}{0} \\
\infty \\
\vdots\end{array}$ & 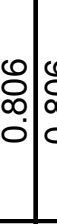 & $\mid$ & 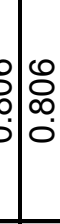 & & $\left|\begin{array}{c}\wp \\
\varnothing \\
\infty \\
0\end{array}\right|$ & & $\begin{array}{l}0 \\
8 \\
\infty \\
\vdots \\
\vdots\end{array}$ & \\
\hline & 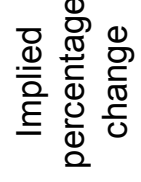 & \begin{tabular}{l}
$\mathcal{N}$ \\
\multirow{f}{*}{} \\
\multirow{N}{*}{}
\end{tabular} & $\frac{N}{N}$ & \begin{tabular}{l}
0 \\
0 \\
0 \\
0 \\
\hdashline \\
\end{tabular} & \begin{tabular}{c}
0 \\
0 \\
0 \\
0 \\
\hdashline \\
1
\end{tabular} & 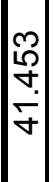 & 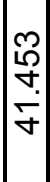 & 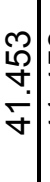 & $\begin{array}{l}m \\
i \\
\dot{v} \\
\dot{\sigma}\end{array}$ & 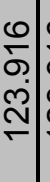 & 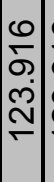 & $\begin{array}{l}0 \\
\sigma \\
\\
\end{array}$ & 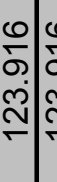 & 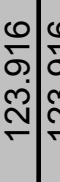 & 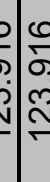 & v̦ & $\begin{array}{l}0 \\
\sigma \\
\\
\end{array}$ & $\begin{array}{c}0 \\
\sigma \\
\\
\stackrel{1}{\sim}\end{array}$ & 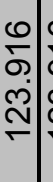 & 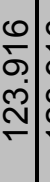 & 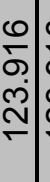 \\
\hline & 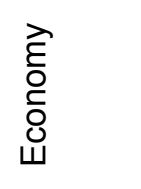 & |山 & 5 & $\begin{array}{l}5 \\
\frac{\bar{\sigma}}{\Phi} \\
\bar{\Phi} \\
\infty\end{array}$ & 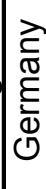 & $\begin{array}{l}\frac{\mathrm{d}}{\mathbb{0}} \\
\frac{\mathrm{d}}{\mathrm{d}}\end{array}$ & 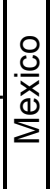 & $\overline{0}$ & $\begin{array}{l}\frac{5}{\mathbb{N}} \\
. \frac{3}{\sqrt{0}} \\
-\end{array}$ & 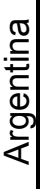 & $\mid$ & $\begin{array}{l}\overline{\bar{N}} \\
\frac{\mathfrak{T}}{\omega} \\
\end{array}$ & 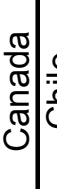 & $\overline{\bar{c}}$ & $\begin{array}{l}\frac{0}{0} \\
= \\
= \\
= \\
=\end{array}$ & 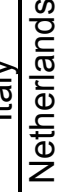 & 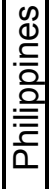 & $\begin{array}{l}. \\
\text { जे } \\
\text { के }\end{array}$ & 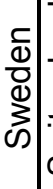 & 交 & $\begin{array}{l}\frac{\bar{c}}{d} \\
\frac{\bar{\pi}}{\bar{\pi}} \\
\frac{2}{1}\end{array}$ \\
\hline
\end{tabular}

